Article

\title{
The Biomass and Physiological Responses of Vallisneria natans (Lour.) Hara to Epiphytic Algae and Different Nitrate-N Concentrations in the Water Column
}

\author{
Fenli Min ${ }^{1,2}$, Jincheng Zuo ${ }^{3}$, Yi Zhang ${ }^{1}$, Qingwei Lin ${ }^{1,2}$, Biyun Liu ${ }^{1, *}$, Jian Sun ${ }^{1,2}$, Lei Zeng ${ }^{1,2}$, \\ Feng $\mathrm{He}^{1, *}$ and Zhenbin $\mathrm{Wu}^{1}$ \\ 1 State Key Laboratory of Freshwater Ecology and Biotechnology, Institute of Hydrobiology, Chinese \\ Academy of Sciences, Wuhan 430072, China; minfenli1989@163.com (F.M.); zhangyi@ihb.ac.cn (Y.Z.); \\ qingweilin1988@163.com (Q.L.); sunjian813@163.com (J.S.); awudiniu@163.com (L.Z.); \\ wuzb@ihb.ac.cn (Z.W.) \\ 2 University of Chinese Academy of Sciences, Beijing 100049, China \\ 3 School of Life Science, Ludong University, Yantai 264025, China; zuojincheng@ldu.edu.cn \\ * Correspondence: liuby@ihb.ac.cn (B.L.); hefeng@ihb.ac.cn (F.H.); \\ Tel.: +86-27-6878-0038 (B.L.); +86-27-6878-0832 (F.H.)
}

Received: 4 September 2017; Accepted: 2 November 2017; Published: 22 November 2017

\begin{abstract}
Increasing $\mathrm{N}$ concentration and the high density of epiphytic algae are both key factors leading to the decline of submerged macrophytes in many eutrophic lakes. In order to investigate the impacts of increased nitrate-N concentration and the growth of epiphytic algae on the decline of submerged vegetation, we conducted a $2 \times 4$ factorial experiment with the submerged macrophyte Vallisneria natans (Lour.) Hara by measuring the biomass of plants and some physiological indexes in leaves of $V$. natans under four nitrate-N concentrations in the water column $(0.5,2.5,5$, and $10 \mathrm{mg} / \mathrm{L}$ ) and two epiphytic groups (epiphytic algae group and no epiphytic algae group). The results suggested that epiphytic algae could impose adverse effects on the biomass accumulation of $V$. natans, while the increasing nitrate- $\mathrm{N}$ concentration $(0.5-10 \mathrm{mg} / \mathrm{L})$ could oppositely promote this process and counteract the adverse effect of epiphytic algae. When nitrate-N concentration was $5 \mathrm{mg} / \mathrm{L}$, the total chlorophyll content in leaves of $V$. natans in the epiphytic algae group was prominently lower compared with the no epiphytic algae group, while MDA, free proline, and anti-oxidant enzyme (SOD, POD, CAT) activities were significantly higher. Overhigh nitrate-N concentration in the water column also directly imposed adverse effects on the physiology of $V$. natans. When nitrate- $\mathrm{N}$ concentration was over $5 \mathrm{mg} / \mathrm{L}$, the total chlorophyll content and free proline decreased in the no epiphytic algae group, while soluble carbohydrates and soluble proteins decreased when nitrate-N was over $2.5 \mathrm{mg} / \mathrm{L}$. Meanwhile, epiphytic algae and nitrate- $\mathrm{N}$ content imposed a synergetic effect on the anti-oxidant enzyme activities of $V$. natans. When nitrate-N concentration was over $5 \mathrm{mg} / \mathrm{L}, \mathrm{SOD}, \mathrm{POD}$, and CAT activities kept constant or decreased, which indicated that the oxidation resistance of $V$. natans was inhibited by stress. Our results indicate that epiphytic algae and increasing nitrate-N concentration in the water column could severally or synergistically impose adverse effects on the physiology of submerged macrophytes and are both key factors leading to the decline of submerged macrophytes.
\end{abstract}

Keywords: Vallisneria natans (Lour.) Hara; Nitrate-N; epiphytic algae; physiological response; biomass; stress 


\section{Introduction}

Aquatic plants, especially submerged macrophytes, play a crucial role in the recovery process of polluted shallow lake ecosystems by providing habitats for a diverse faunal community [1,2], sequestering carbon and nutrients through absorption by the root and stem [3], and reducing phytoplankton biomass by either direct or indirect pathways [4,5]. However, the decline of submerged macrophytes continually happens in many eutrophic lakes throughout the world as a result of eutrophication with increasing nutrients [6,7]. It is well known that phosphorus $(\mathrm{P})$ is often considered to be the most crucial growth limiting factor for plants in lakes [8,9], but the role of nitrogen $(\mathrm{N})$ in submerged macrophytes recession has recently received increasing attention [10]. Yu et al. [11] demonstrated that stress exerted by high nitrogen may be responsible for the decline in leaf length, leaf mass, and root length of Vallisneria natans (Lour.) Hara. Barker et al. [12] suggested that the loss of species diversity of submersed macrophytes was related to increasing $\mathrm{N}$ loading in the water body. The elevating nitrate- $\mathrm{N}$ concentration was considered to be the reason for plant species richness declines according to studies conducted in Polish and British lakes [13].

While the use of phosphate fertilizers tends to be constant worldwide [14], the use of nitrogenous fertilizers is still increasing, which may potentially have disadvantageous effects of nitrogen on submerged macrophytes. The excessive use of manure and synthetic fertilizers could lead to the leaching of nitrate- $\mathrm{N}\left(\mathrm{NO}_{3}{ }^{-}\right)$from agricultural land, greatly increasing $\mathrm{NO}_{3}{ }^{-}$concentrations of groundwater and surface water bodies [15]. As a consequence, many shallow freshwater systems suffer from high $\mathrm{NO}_{3}{ }^{-}$loading (100-1000) $\mu \mathrm{mol} \mathrm{L}{ }^{-1}$ of the water column [16]. Ammonia-N is the dominant $\mathrm{N}$ form in the interstitial water, while nitrate- $\mathrm{N}$ usually exists in much higher concentrations in the overlying water [17]. Rooted submerged macrophytes are capable of taking up $\mathrm{NH}_{4}{ }^{+}$and $\mathrm{NO}_{3}{ }^{-}$ through both roots and shoots from ambient environments [18,19]. Burkholder et al. [20] found that water-column nitrate enrichment promoted the decline of eelgrass Zostera marina. While many studies focused on the effects of ammonia-N on submerged macrophytes [21,22], the effects of high nitrate-N concentrations on the growth of submerged macrophytes are not yet well understood.

Eutrophic water with a high nitrogen content always brings about an increase of planktonic algae and epiphytic algae $[23,24]$. The decline of submerged macrophytes is often accompanied with a high planktonic algae density in the eutrophic lakes $[25,26]$. However, the overgrowth of epiphytic algae was seen to occur earlier than planktonic algae in eutrophic lakes and the reduction of submerged macrophytes was connected with a high epiphytic algae density $[27,28]$. In previous studies by Jones and Sayer [29] and Bécares et al. [30], a 50\% reduction of submerged macrophyte biomass

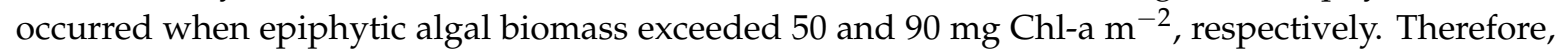
the overgrowth of epiphytic algae rather than planktonic algae may be the most important factor leading to the loss of submerged macrophytes [23,31]. In fact, the results of many previous studies have suggested that the presence of dense epiphytic algae populations inhibits the growth of submerged macrophytes [32-34], mainly by reducing light and nutrient availability for the plants [29,35], which may further lead to the loss of submerged macrophytes. As a consequence, the clear-water state in shallow lakes is transformed into a turbid-water state with a high density of phytoplankton [36,37]. However, little direct evidence exists and the understanding of its underlying mechanisms is limited. Thus, combined effects of epiphytic algae and different nitrate- $\mathrm{N}$ concentrations on submerged macrophytes are worth studying.

In this study, Vallisneria natans (Lour.) Hara, a perennial, rooted, submerged macrophyte, was selected for its wide distribution and tolerance of eutrophic conditions. The community composition and biomass of epiphytic algae, biomass of the plants, and some physiological indexes, such as Chlorophyll content, malondialdehyde (MDA) content, free proline content, soluble carbohydrates, soluble proteins, and anti-oxidant enzymes (SOD, POD, CAT) activities in the leaves of $V$. natans under four nitrate-N concentrations with two epiphytic algal statuses were measured. Chlorophyll content in leaves of plants is responsible for the absorption and transformation of light energy for photosynthesis in plants and reflects the photosynthetic ability of plants. MDA is one 
of the end products of membrane lipid peroxidation and can be used as an important index of physiological stress. Free proline content will largely accumulate in plants under stress conditions. Soluble carbohydrates and soluble proteins are important metabolites in plant metabolism and their content will change under stress conditions. SOD, POD, and CAT are important anti-oxidant enzymes in the protective defense system to eliminate or reduce reactive oxygen species (ROS) in plants and their activities reflect the stress resistance of plants. This study aimed to explore the effects of epiphytic algae and different nitrate- $\mathrm{N}$ concentrations on the biomass accumulation and physiology of $V$. natans and provides a theoretical foundation for the restoration of eutrophic lakes.

\section{Materials and Methods}

\subsection{Materials and Study Site}

The experiment was conducted at the Hangzhou field station $\left(30^{\circ} 12^{\prime} 28^{\prime \prime} \mathrm{N}, 120^{\circ} 8^{\prime} 42^{\prime \prime} \mathrm{E}\right)$ of the Institute of Hydrobiology, Chinese Academy of Science, for the national water project. Sediments less than $15 \mathrm{~cm}$ in depth from the top surface layer were collected for use from Hangzhou West Lake, a freshwater lake in China which was added to the world heritage list in 2011. Total nitrogen of the sediments was $6.08 \pm 0.35 \mathrm{mg} / \mathrm{g}$ dry weight $(\mathrm{DW})$, total phosphorus was $1.54 \pm 0.21 \mathrm{mg} / \mathrm{g}$ $\mathrm{DW}$, and total organic matter content was $13 \pm 2.3 \% \mathrm{DW}$. In order to remove impurities (benthonic faunas and others), sediments were transported to the laboratory, and wet-sieved through a $2 \mathrm{~mm}$ sieve. Then, the sediments were air-dried at $40{ }^{\circ} \mathrm{C}$ to kill any invertebrates, passed through a $0.5 \mathrm{~mm}$ sieve, and mixed thoroughly to evenly distribute the physical and chemical properties. V. natans of a similar size (fresh weight $5.05 \pm 0.36 \mathrm{~g}$; length $15 \pm 1.5 \mathrm{~cm}$; mean $\pm \mathrm{SE}$ ) and epiphytic algae were collected from the west part of Hangzhou West Lake. Epiphytic algae was collected from several plant species from a wide range of nutrient conditions by shaking and brushing, and mainly belonged to 12 genera. Tap water was kept for $24 \mathrm{~h}$ before use for the experiment. Moreover, twenty-four aquariums (length $\times$ width $\times$ height, $25 \mathrm{~cm} \times 25 \mathrm{~cm} \times 50 \mathrm{~cm}$ ), $\mathrm{KNO}_{3}$, and $\mathrm{NaNO}_{3}$ were used for the experiment. $\mathrm{KNO}_{3}$ and $\mathrm{NaNO}_{3}$ were used to maintain the designed nitrate- $\mathrm{N}$ concentrations in the aquariums and they were added with a 1:1 ratio.

\subsection{Experimental Design}

Individuals of $V$. natans of a similar size were equally planted into the 24 aquariums, which were injected with $10 \mathrm{~cm}$ thick homogeneous sediment in advance. Each aquarium was planted with 12 individuals of $V$. natans. Then, tap water was poured into each aquarium slowly along the glass wall to a $30 \mathrm{~cm}$ water depth. All aquariums were maintained under the same conditions outside the field station for a 15 day acclimation before the experiment.

The experimental set-up was based on a $2 \times 4$ factorial design with two epiphytic algae statuses (epiphytic algae group and no epiphytic algae group) and four levels of nitrate-N concentrations in the water column. The four nitrate-N concentrations of the water column were set as $0.5 \mathrm{mg} / \mathrm{L}, 2.5 \mathrm{mg} / \mathrm{L}$, $5 \mathrm{mg} / \mathrm{L}$, and $10 \mathrm{mg} / \mathrm{L}$ with a moderate phosphorus concentration at $0.02-0.04 \mathrm{mg} / \mathrm{L}$. Each treatment was conducted with three replicates. In the no epiphytic algae group, snail (Bellamya aeruginosa) grazing prevented the establishment of algae, as per a preliminary study. One snail weighing about $0.25 \mathrm{~g}$ was added to each aquarium in the no epiphytic algae group. In the epiphytic algae group, a $30 \mathrm{~mL}$ mixed epiphytic algal inoculum was added to each treatment. The community composition of the epiphytic algal inoculum mainly belonged to 12 genera, including Aulacoseira, Cyclotella, Navicula, Cymbella, Aphanothece, Chlorella, Fragilaria, Synedra, Achnanthes, Oscillatoria, Lyngbya, and Pseudanabaena. In previous researches, Song et al. (2015) and Yi et al. (2016) found that all of these 12 algal taxa could be epiphytic on artificial substrates and submerged macrophytes [38,39]. In order to avoid the influence of phytoplankton, one third of the water in the aquariums was replaced by tap water. Water lost by evaporation was also supplemented with tap water. Nitrate- $\mathrm{N}$ concentration of each aquarium was determined every day, using the spectrophotometric method with phenol disulfonic acid. $\mathrm{KNO}_{3}$ 
and $\mathrm{NaNO}_{3}$ concentrated solutions were used to maintain the given nitrate- $\mathrm{N}$ concentrations in the water column and they were added with a 1:1 ratio.

The experiment was started on 3 August and ended on 28 August 2016. After cultivation for 25 days, all $V$. natans plants were harvested and fresh weights were recorded, respectively. Some of the plant samples were collected and frozen at $-20{ }^{\circ} \mathrm{C}$ for the determination of chlorophyll (chl-a and chl-b), malondialdehyde (MDA), free proline content, antioxidant enzyme activities (SOD, POD, CAT), soluble protein, and soluble carbohydrate. Other plant samples were used for epiphytic algae analysis. Epiphytic algae specimens were detached from the leaves of $V$. natans (about an area of $30 \mathrm{~cm}^{2}$ ) in $100 \mathrm{~mL}$ distilled water using a soft brush. Subsamples of $10 \mathrm{~mL}$ were fixed with Lugol iodine liquid and maintained at $4{ }^{\circ} \mathrm{C}$ for further quantification and classification. Meanwhile, $50 \mathrm{~mL}$ subsamples were filtered onto GF/C $(0.45 \mathrm{~mm})$ glass fiber filters and frozen at $-20^{\circ} \mathrm{C}$ for epiphytic algae chlorophyll analysis.

\subsection{Epiphytic Algae Quantification and Classification}

The biomass of epiphytic algae was represented by the chlorophyll in content per unit leaf surface area of $V$. natans. The prepared frozen filters with epiphytic algae were ground in a mortar with $6 \mathrm{~mL}$ acetone $(90 \%)$. Then, the paste was transferred to a centrifuge tube, and the mortar was washed two to three times with $4 \mathrm{~mL}$ acetone $(90 \%)$ and poured into the tube. The tube was centrifuged for $20 \mathrm{~min}$ at $7000 \mathrm{r} / \mathrm{min}$ under $4{ }^{\circ} \mathrm{C}$. The liquid supernatant was measured using a fluorescence spectrophotometer according to the method described by Arnon [40]. The preserved subsample for identifying epiphytic algae was shaken well and $0.1 \mathrm{~mL}$ of the sample was dropped into an algae cell counter and epiphytic algae specimens were identified and counted using an OLYMPUS BH-2 microscope according to Zhang and Huang [41].

2.4. Chlorophyll, Malondialdehyde (MDA), Free Proline, Soluble Carbohydrates, and Soluble Proteins Analysis of $V$. natans

Total chlorophyll content of $V$. natans was extracted from $0.2 \mathrm{~g}$ fresh apical leaves in $25 \mathrm{~mL}$ of $95 \%$ ethanol in the dark for $48 \mathrm{~h}$ at $4{ }^{\circ} \mathrm{C}$. Then, the supernatant was used to measure the absorbance on a spectrophotometer at 645 and $663 \mathrm{~nm}$, respectively. Chl-a and Chl-b were calculated by the equation of Arnon [40] and expressed in mg pigments/g fresh weight.

The MDA content of $V$. natans indicated the level of membrane lipid peroxidation and was determined using the Thiobarbituric acid (TBA) method [42]. Free proline was measured with the acidic ninhydrin coloring with spectrophotometry and the standard curve method [43]. Soluble carbohydrates and proteins were extracted from $0.2 \mathrm{~g}$ leaves with $5 \mathrm{~mL} 80 \%$ ethanol at $60{ }^{\circ} \mathrm{C}$ for $10 \mathrm{~min}$ and centrifuged at $10,000 \times g$ for $20 \mathrm{~min}$. The supernatant was used for measurements. A soluble carbohydrate measurement was conducted using the anthrone method according to Yemm and Willis [44]. Soluble protein concentration was measured using the Coomassie brilliant blue-dye binding method [45].

\subsection{Enzyme Extraction and Assay of Superoxide Dismutase (SOD), Peroxidase (POD), and Catalase (CAT) Activity}

The enzymes were extracted from an $800 \mathrm{mg}$ sample in $8 \mathrm{~mL}$ precooled $50 \mathrm{mM}$ PBS (pH 7.0) containing $1 \mathrm{mM}$ EDTA and 1\% $(w / v)$ poly vinylpyrrolidone as an enzyme stabilizer [21]. In brief, a $0.8 \mathrm{~g}$ sample of plant material was ground in liquid nitrogen and homogenized in $8 \mathrm{~mL}$ of $50 \mathrm{mM}$ potassium phosphate buffer ( $\mathrm{pH} 7.0$ ) containing $1 \mathrm{mM}$ EDTA and $1 \%$ poly vinylpyrrolidone. The homogenate was centrifuged at $15,000 \times g$ for $20 \mathrm{~min}$ at $4{ }^{\circ} \mathrm{C}$. The supernatant was the crude enzyme which was used to measure the activity of superoxide dismutase (SOD), catalase (CAT), and guaiacol peroxidase (POD).

SOD activity was measured by monitoring the inhibition of the photochemical reduction of nitro-blue tetrazolium (NBT), POD activity was determined as oxidation of guaiacol by $\mathrm{H}_{2} \mathrm{O}_{2}$, and CAT 
activity was determined by measuring the change of absorbance at $240 \mathrm{~nm}$ that accompanied the consumption of $\mathrm{H}_{2} \mathrm{O}_{2}$ according to the methods of $\mathrm{Li}$ [46]. Enzyme activities of SOD, POD, and CAT were expressed as $\mathrm{U} / \mathrm{mg}$ protein.

\subsection{Statistical Analysis}

Data shown in the figures is the mean of three replicates and presented as mean \pm SE. Oneand two-way analysis of variance (ANOVA) were used to analyze the effects of increasing nitrate-N concentration, epiphytic algae, and their interactions on the biomass of $V$. natans and physiological parameters (total chlorophyll (chl-t), chl-a/chl-b, MDA, free proline, soluble proteins, soluble carbohydrates, and antioxidant enzyme activities (SOD, POD, CAT)). Homogeneity of variances was ensured with Levene's test before the ANOVA tests. Post hoc comparisons for all analyses were made with the Student-Newman-Keuls (SNK) test. The level of statistical significance was set at $p<0.05$. SPSS 21.0 software was used to perform all the statistical analyses and Origin Pro 8.0 was used to plot the experimental data.

\section{Result}

\subsection{Biomass of $V$. natans}

Biomass accumulation of $V$. natans was significantly affected by nitrate-N concentration and epiphytic algae (Table 1). The total biomass of $V$. natans in the epiphytic algae group was systematically lower than that in the no epiphytic algae group under different nitrate- $\mathrm{N}$ concentrations. The biomass of $V$. natans in the no epiphytic algae group gradually increased as the nitrate- $\mathrm{N}$ concentration elevated from $0.5 \mathrm{mg} / \mathrm{L}$ to $10 \mathrm{mg} / \mathrm{L}$. However, the biomass of $V$. natans in the epiphytic algae group decreased when the nitrate- $\mathrm{N}$ concentration of the water column was $0.5-2.5 \mathrm{mg} / \mathrm{L}$, and increased when the total nitrogen concentration of the water column was $2.5-10 \mathrm{mg} / \mathrm{L}$. Compared with the no epiphytic algae group, the biomass in the epiphytic algae group decreased by approximately $12.6 \%, 33.3 \%$, $23.8 \%$, and $13.8 \%$, respectively, in the treatments of $0.5,2.5,5$, and $10 \mathrm{mg} / \mathrm{L}$ nitrate-N concentrations. The testing result of one-way ANOVA showed that the biomass of $V$. natans exhibited a significant difference between the epiphytic algae group and no epiphytic algae group when nitrate-N was 2.5-5 mg/L ( $p<0.05)$ (Figure 1).

Table 1. Results of two-way ANOVA on the effects of increasing nitrate-N and epiphytic algae on the biomass and physiological parameters of $V$. natans. SC and SP, respectively, represent soluble carbohydrates and soluble proteins. ${ }^{*} p<0.05 ;{ }^{* *} p<0.01 ;{ }^{* * *} p<0.001$.

\begin{tabular}{ccccccc}
\hline & \multicolumn{2}{c}{ Nitrate-N } & \multicolumn{2}{c}{ Epiphytic Algae } & \multicolumn{2}{c}{ Nitrate-N $\times$ Epiphytic Algae } \\
\hline Parameters & $F$ Value & $p$ Value & $F$ Value & $p$ Value & $F$ Value & $p$ Value \\
\hline Biomass & 4.987 & $0.012^{*}$ & 20.3 & $<0.001^{* * *}$ & 2.449 & 0.101 \\
Chl-t & 23.721 & $<0.001^{* * *}$ & 13.37 & $0.002^{* *}$ & 1.627 & 0.223 \\
Chl-a /Chl-b & 41.419 & $<0.001^{* * *}$ & 3.091 & 0.098 & 5.515 & $0.009^{* *}$ \\
MDA & 19.318 & $<0.001^{* * *}$ & 54.093 & $<0.001^{* * *}$ & 7.156 & $0.003^{* *}$ \\
Free proline & 22.356 & $<0.001^{* * *}$ & 1.628 & $0.22^{* *}$ & 1.77 & $0.193^{* *}$ \\
SC & 37.636 & $<0.001^{* * *}$ & 7.808 & $0.013^{*}$ & 9.697 & $0.001^{* *}$ \\
SP & 10.578 & $<0.001^{* * *}$ & 0.039 & $0.847^{* *}$ & 2.819 & $0.072^{* * *}$ \\
SOD & 7.132 & $0.003^{* *}$ & 33.513 & $<0.001^{* *}$ & 10.388 & $<0.001^{* * *}$ \\
POD & 75.899 & $<0.001^{* * *}$ & 16.473 & $0.001^{* *}$ & 20.205 & $<0.001^{* * *}$ \\
CAT & 32.843 & $<0.001^{* * *}$ & 16.065 & $0.001^{* *}$ & 13.838 & $<0.001^{* * *}$ \\
\hline
\end{tabular}




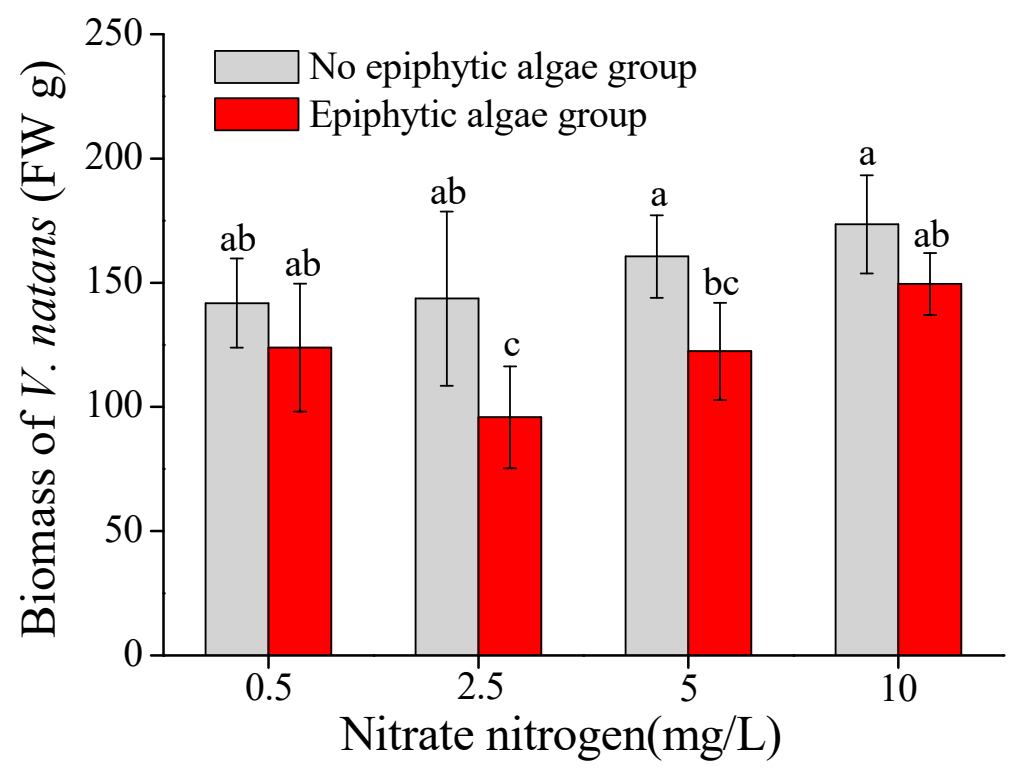

Figure 1. Biomass of $V$. natans (mean $\pm \mathrm{SE}, n=3$ ) in the epiphytic algae group and no epiphytic algae group under four nitrate- $\mathrm{N}$ concentrations. Bars with different letters indicate significant differences among treatments $(p<0.05)$.

\subsection{Biomass and Community Composition of Epiphytic Algae}

After cultivation under four nitrate-N levels, the epiphytic algal biomass varied and community composition on the surface of $V$. natans differed from the original community. When the nitrate-N concentration was $0.5 \mathrm{mg} / \mathrm{L}$, epiphytic algal biomass (expressed by chlorophyll-a concentration) was relatively significantly lower compared with those at higher nitrate- $\mathrm{N}$ concentrations $(p<0.05)$, and when nitrate- $\mathrm{N}$ was $2.5-5 \mathrm{mg} / \mathrm{L}$, epiphytic algal biomass was greater, and even higher than that of $10 \mathrm{mg} / \mathrm{L}$ nitrate- $\mathrm{N}$ treatment. The specific order of nitrate- $\mathrm{N}$ in favor of epiphytic algal biomass was $2.5 \mathrm{mg} / \mathrm{L}>5 \mathrm{mg} / \mathrm{L}>10 \mathrm{mg} / \mathrm{L}>0.5 \mathrm{mg} / \mathrm{L}$ (Figure 2).

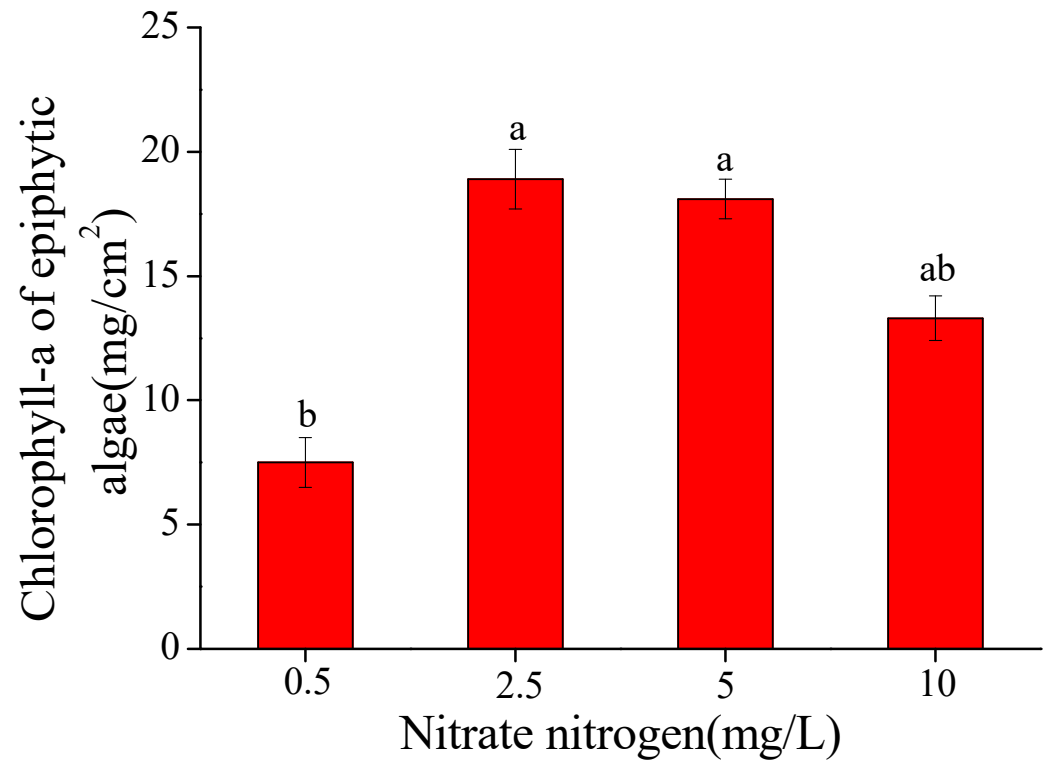

Figure 2. Chlorophyll-a content of epiphytic algae per unit leaf area of $V$. natans (mean $\pm \mathrm{SE}, n=3$ ) in the epiphytic algae group under four nitrate- $\mathrm{N}$ concentrations. Bars with different letters indicate significant differences among treatments $(p<0.05)$. 
The community composition of original epiphytic algae mainly belonged to 12 genera, including Aulacoseira, Cyclotella, Navicula, Cymbella, Aphanothece, Chlorella, Fragilaria, Synedra, Achnanthes, Oscillatoria, Lyngbya and Pseudanabaena. Aulacoseira, Cyclotella, Navicula, Aphanothece, Fragilaria, and Achnanthes, which were dominant algae and accounted for $18 \%, 10 \%, 15 \%, 15 \%, 11 \%$, and $10 \%$, respectively. At the end of the experiment, as nitrate- $\mathrm{N}$ increased, relative abundances of Oscillatoria, Lyngbya, and Pseudanabaena increased at first, and then decreased when the total nitrogen was $10 \mathrm{mg} / \mathrm{L}$. Relative abundances of Navicula, Aulacoseira, and Chlorella decreased when nitrate-N was $0.5-5 \mathrm{mg} / \mathrm{L}$ and then increased when nitrate- $\mathrm{N}$ was $5-10 \mathrm{mg} / \mathrm{L}$ (Figure 3).

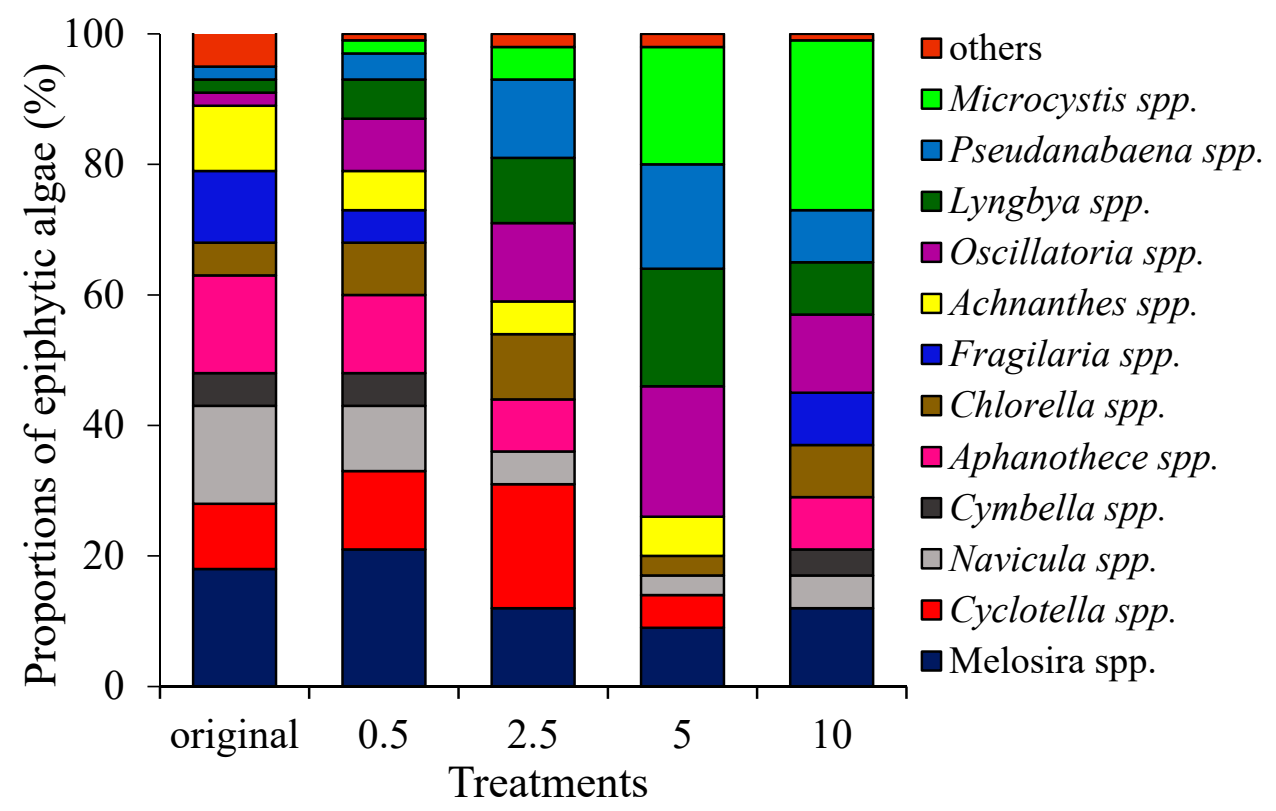

Figure 3. The main community composition of epiphytic algae of the original source and that after varied under different nitrate- $\mathrm{N}$ concentrations.

When the nitrate-N concentration was $0.5 \mathrm{mg} / \mathrm{L}$, Aulacoseira, Cyclotella, Navicula, and Aphanothece were dominant algae and accounted for $21 \%, 12 \%, 10 \%$, and $12 \%$, respectively. When the nitrate- $\mathrm{N}$ concentration was $2.5 \mathrm{mg} / \mathrm{L}$, relative abundances of Oscillatoria, Lyngbya, and Pseudanabaena increased to $12 \%, 10 \%$, and $12 \%$, respectively. As nitrate-N increased to $5 \mathrm{mg} / \mathrm{L}$, Oscillatoria, Lyngbya, Pseudanabaena, and Microcystis were dominant and accounted for $20 \%, 18 \%, 16 \%$, and 18\%, respectively. When the nitrate- $\mathrm{N}$ concentration was $10 \mathrm{mg} / \mathrm{L}$, relative abundances of Oscillatoria, Lyngbya and Pseudanabaena decreased, but relative abundances of Navicula, Aulacoseira, Chlorella, and Microcystis increased on the contrary. The dominant epiphytic algal genera were Aulacoseira, Oscillatoria, and Microcystis, accounting for 12\%, 12\%, and 26\%, respectively (Figure 3).

\subsection{Total Chlorophyll Content and Chl-a/Chl-b Ratio in Leaves of V. natans}

The total chlorophyll (chl-t) content in the leaves of $V$. natans was significantly influenced by both nitrate-N concentration and epiphytic algae (Table 1). In the epiphytic algae group, chl-t content was lower than in the no epiphytic algae group. The chl-t content of $V$. natans gradually increased when the nitrate- $\mathrm{N}$ concentration was $0.5-5 \mathrm{mg} / \mathrm{L}$, and decreased when the nitrate- $\mathrm{N}$ concentration was $5-10 \mathrm{mg} / \mathrm{L}$ in both the epiphytic algae group and no epiphytic algae group. When the nitrate-N concentration was $5 \mathrm{mg} / \mathrm{L}$, the chl-t content was prominently different between the epiphytic algae group and no epiphytic algae group $(p<0.05)$. The chl-a/chl-b ratio was significantly affected by interactions of increasing nitrate-N concentration and epiphytic algae (Table 1). The chl-a/chl-b ratio decreased as nitrate- $\mathrm{N}$ concentration increased from 0.5 to $10 \mathrm{mg} / \mathrm{L}$ in the epiphytic algae group. 
However, in the no epiphytic algae group, the ratios decreased when total nitrogen was $0.5-5 \mathrm{mg} / \mathrm{L}$, but increased when total nitrogen was 5-10 mg/L (Figure 4).

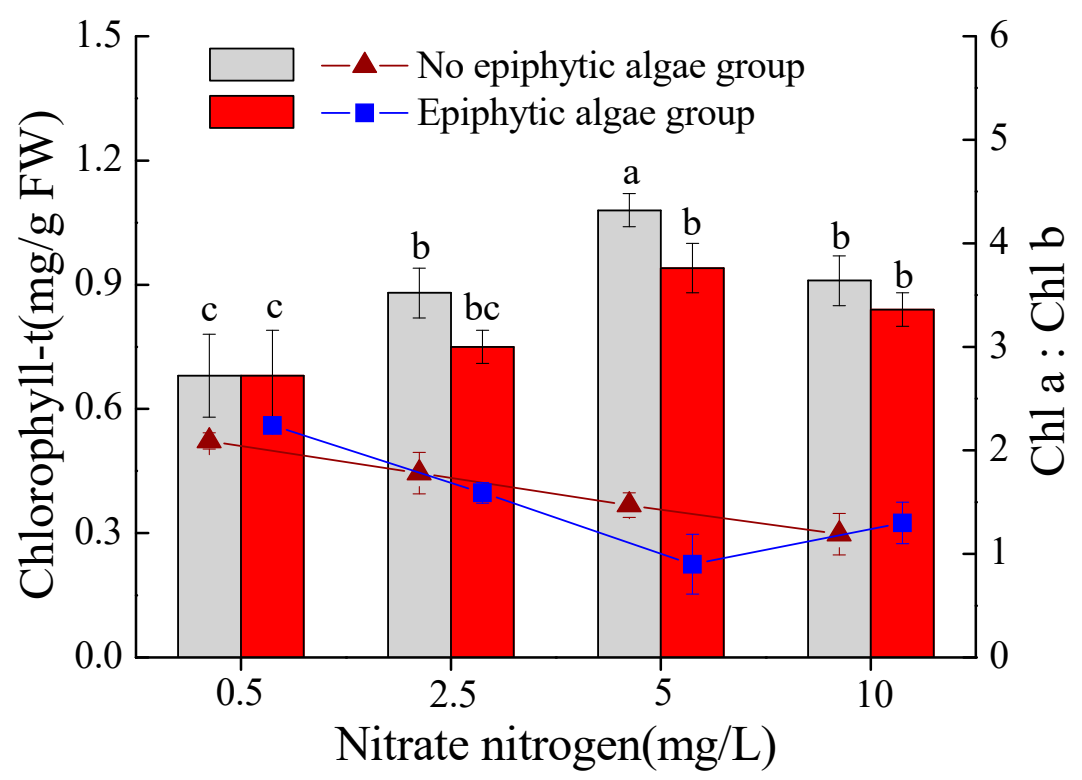

Figure 4. Total chlorophyll content and the chl-a/chl-b ratio of $V$. natans (mean $\pm \mathrm{SE}, n=3$ ) in the epiphytic algae group and no epiphytic algae group under four nitrate-N concentrations. Bars with different letters indicate significant differences among treatments $(p<0.05)$.

\subsection{MDA Content in Leaves of V. natans}

Nitrate-N concentration, epiphytic algae, and their interactions all showed significant influences on the MDA content in leaves of $V$. natans (Table 1). The MDA content of $V$. natans in the epiphytic algae group was systematically higher than that in the no epiphytic algae group when the nitrate-N concentration was $0.5-2.5 \mathrm{mg} / \mathrm{L}(p<0.05)$. In the epiphytic algae group, the MDA content of $V$. natans gradually increased and was maintained at a high level as the nitrate- $\mathrm{N}$ concentration increased from 0.5 to $10 \mathrm{mg} / \mathrm{L}$. However, in the no epiphytic algae group, the MDA content of V. natans stayed at a comparatively low level when the nitrate- $\mathrm{N}$ concentration was $0.5-2.5 \mathrm{mg} / \mathrm{L}$ (Figure $5 \mathrm{~A}$ ).

\subsection{Free Proline Content in Leaves of V. natans}

Free proline content was significantly influenced by different nitrate- $\mathrm{N}$ concentrations in the water column (Table 1). Irrespective of the algae group, the free proline content of $V$. natans gradually increased when the nitrate- $\mathrm{N}$ concentration of the water column was $0.5-5 \mathrm{mg} / \mathrm{L}$, and decreased when the total nitrogen was $5-10 \mathrm{mg} / \mathrm{L}$. The values of free proline content were systematically higher in the epiphytic algae group than in the no epiphytic algae group, except for one value when the nitrate- $\mathrm{N}$ concentration was $0.5 \mathrm{mg} / \mathrm{L}$, which was a pretty low level. The free proline content of $V$. natans showed significant differences between the epiphytic algae group and no epiphytic algae group when nitrate- $\mathrm{N}$ was $5 \mathrm{mg} / \mathrm{L}(p<0.05)$ (Figure 5B).

\subsection{Soluble Carbohydrates in Leaves of V. natans}

Soluble carbohydrates content in leaves of $V$. natans was significantly influenced by nitrate-N concentration, epiphytic algae, and their interactions (Table 1). Soluble carbohydrates content increased when the nitrate- $\mathrm{N}$ concentration was $0.5-2.5 \mathrm{mg} / \mathrm{L}$ in both the epiphytic algae group and no epiphytic algae group $(p<0.05)$, but slightly decreased when the nitrate- $\mathrm{N}$ concentration was $2.5-10 \mathrm{mg} / \mathrm{L}$. The SC content of $V$. natans in the epiphytic algae group was lower than that in the no epiphytic algae group, but not significantly so $(p>0.05)$ (Figure $5 C$ ). 


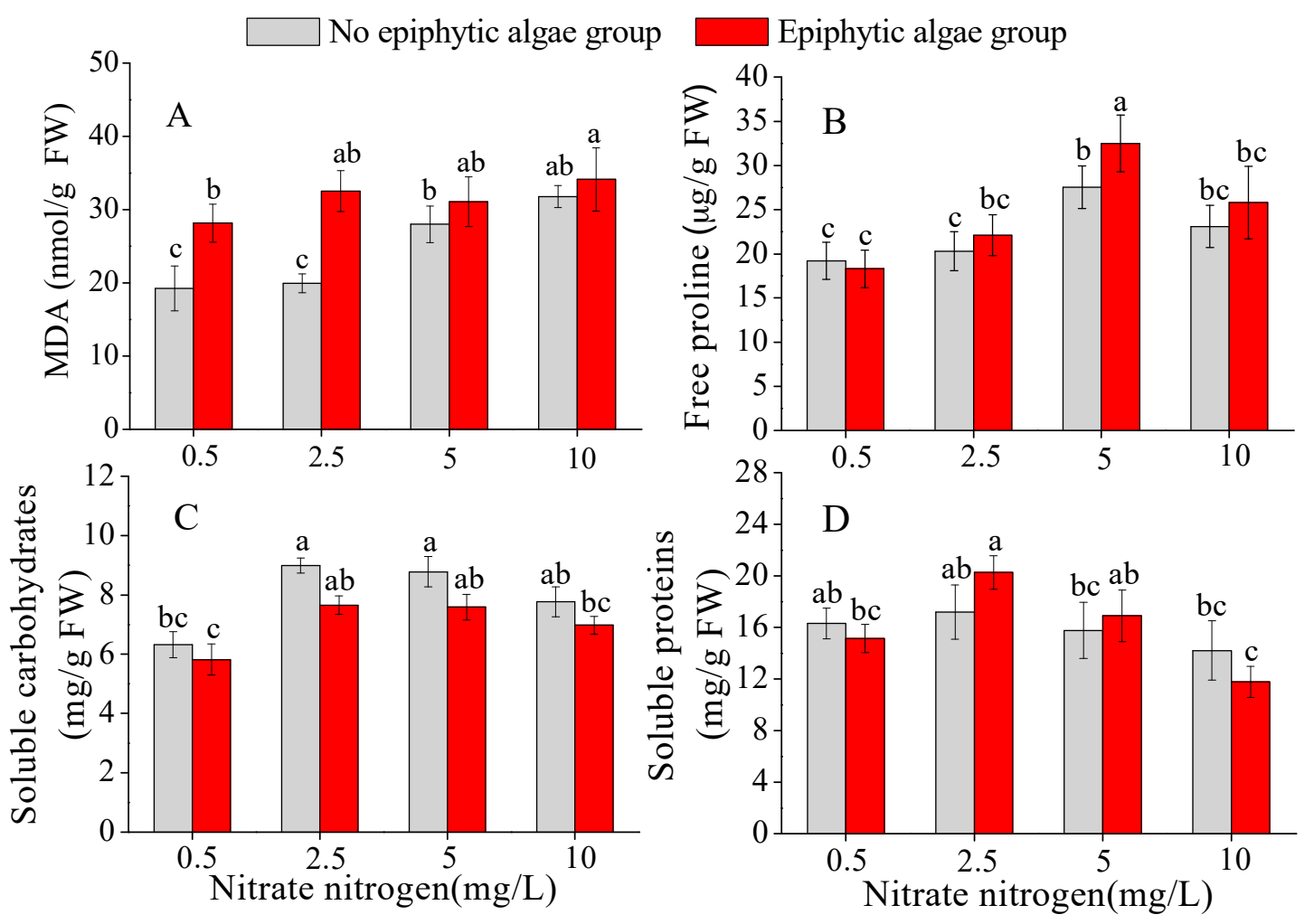

Figure 5. The MDA content (A); free proline content (B); soluble carbohydrates (C); and soluble proteins (D) of $V$. natans (mean $\pm \mathrm{SE}, n=3$ ) in the epiphytic algae group and no epiphytic algae group under four nitrate-N concentrations. Bars with different letters indicate significant differences among treatments $(p<0.05)$.

\subsection{Soluble Proteins in Leaves of V. natans}

Soluble proteins content in the leaves of $V$. natans was significantly influenced by nitrate-N concentration (Table 1). Soluble protein content of $V$. natans in the epiphytic algae group increased as nitrate- $\mathrm{N}$ rose from $0.5 \mathrm{mg} / \mathrm{L}$ to $2.5 \mathrm{mg} / \mathrm{L}$, and decreased when nitrate- $\mathrm{N}$ concentration was $2.5-10 \mathrm{mg} / \mathrm{L}$. However, in the no epiphytic algae group, no significant difference of soluble proteins content was observed in treatments of different nitrate-N concentrations $(p>0.05)$ (Figure 5D).

\subsection{Antioxidant Enzyme Activity (SOD, POD, CAT) in Leaves of V. natans}

SOD, POD, and CAT activities were significantly influenced by nitrate- $\mathrm{N}$ concentration, epiphytic algae, and their interactions (Table 1). SOD activity in the leaves of $V$. natans in the epiphytic algae group increased as the nitrate-N concentration rose from $0.5 \mathrm{mg} / \mathrm{L}$ to $5 \mathrm{mg} / \mathrm{L}$ and showed little increase when nitrate- $\mathrm{N}$ was $10 \mathrm{mg} / \mathrm{L}$, while a sustaining increase was observed in the no epiphytic algae group. Compared with the no epiphytic algae group, the SOD activity of $V$. natans in the epiphytic algae group increased averagely by $14.6 \%, 20.3 \%, 29.5 \%$, and $18.7 \%$, respectively, in treatments of 0.5 , 2.5, 5, and $10 \mathrm{mg} / \mathrm{L}$ nitrate-N concentrations (Figure 6a). POD and CAT activities in leaves of $V$. natans in the epiphytic algae group showed a similar trend with an increase at $0.5-5 \mathrm{mg} / \mathrm{L}$ nitrate- $\mathrm{N}$ content and a slight decrease at $5-10 \mathrm{mg} / \mathrm{L}$ nitrate- $\mathrm{N}$ content, while a sustaining increase was observed in the no epiphytic algae group as the nitrate-N concentration increased. POD and CAT activities of $V$. natans in the epiphytic algae group were systematically higher than that in the no epiphytic algae group. In comparison to the no epiphytic algae group, the average POD activity of $V$. natans leaves in the epiphytic algae group increased by $20.2 \%, 32 \%, 42 \%$, and $14.3 \%$, respectively, in treatments of $0.5,2.5$, 5 , and $10 \mathrm{mg} / \mathrm{L}$ nitrate-N concentrations, while the CAT activity simultaneously increased by $16.5 \%$, $21.6 \%, 25 \%$, and $6 \%$, respectively (Figure $6 \mathrm{~b}, \mathrm{c}$ ). Compared to the no epiphytic algae group, SOD, POD, 
and CAT activities were significantly higher $(p<0.01)$ in the epiphytic algae group when the nitrate-N concentration was $5 \mathrm{mg} / \mathrm{L}$ (Figure 6).
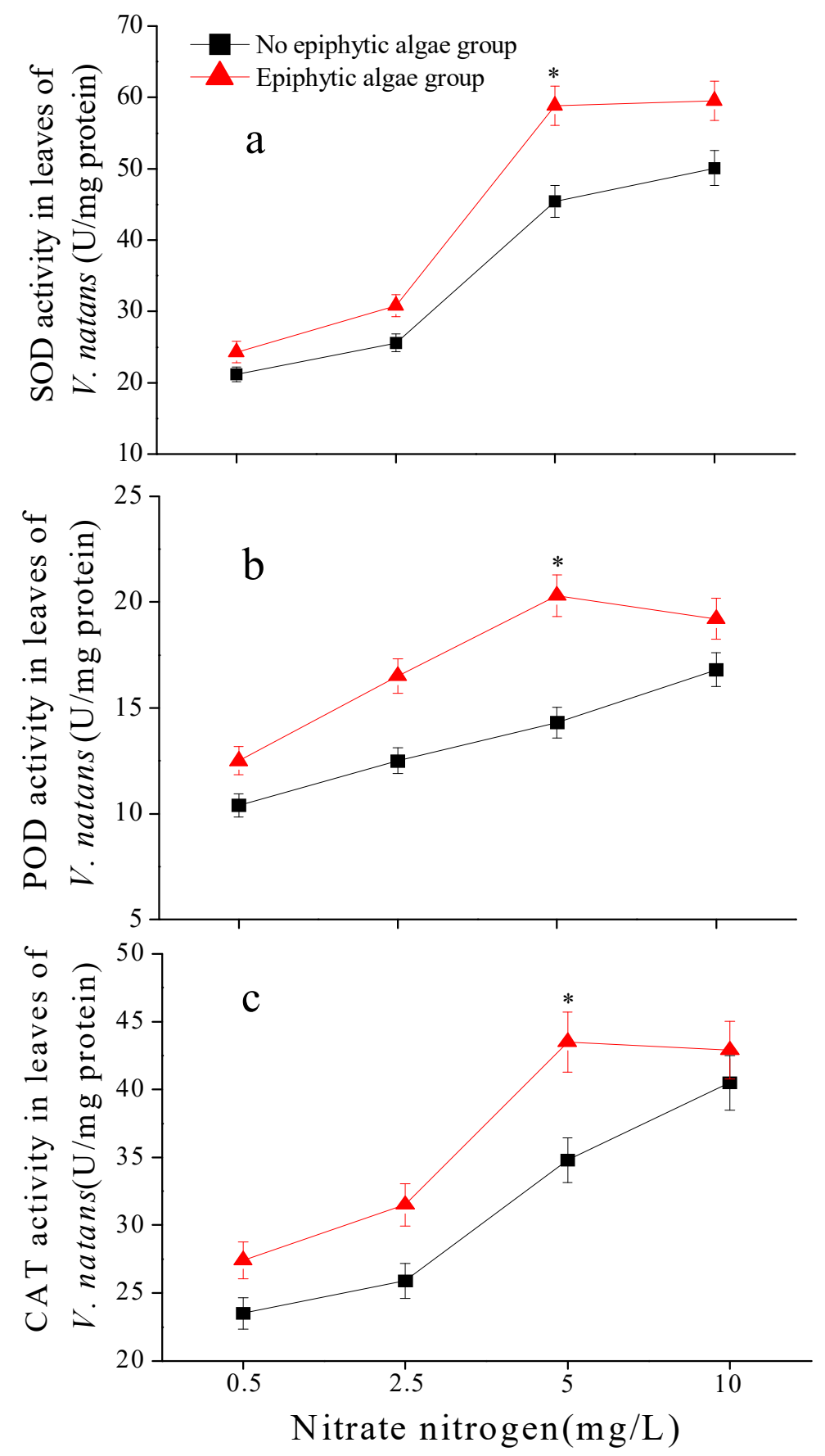

Figure 6. Antioxidant enzyme activity (POD, SOD, CAT) in leaves of $V$. natans (mean $\pm \mathrm{SE}, n=3$ ) in the epiphytic algae group and no epiphytic algae group under four nitrate-N concentrations. Subfigures $(\mathbf{a}-\mathbf{c})$ represent the antioxidant enzyme activities of POD, SOD, and CAT, respectively. Bars with a "*” sign show a significant difference between two epiphytic algae statuses $(p<0.01)$.

\section{Discussion}

Some researchers argue that a mutualistic relationship existed between submerged macrophytes and epiphytic algae, which was the result of coevolution [35,47]. However, in this study, the biomass of $V$. natans in the epiphytic algae group was significantly lower than that in the no epiphytic algae group 
when the nitrate- $\mathrm{N}$ concentration was $2.5-5 \mathrm{mg} / \mathrm{L}$. The result indicates that epiphytic algae imposed a prominent adverse effect on the biomass accumulation of $V$. natans, especially when the nitrate- $\mathrm{N}$ concentration was $2.5-5 \mathrm{mg} / \mathrm{L}$, at which point the epiphytic algal biomass attached on leaves of $V$. natans was particularly high. The adverse effect of epiphytic algae on the host plants was consistent with the result of some other previous studies $[33,48]$. As the nitrate- $\mathrm{N}$ concentration increased from 2.5 to $10 \mathrm{mg} / \mathrm{L}$, the biomass of $V$. natans in the epiphytic algae group gradually increased, suggesting that increasing the nitrate- $\mathrm{N}$ concentration could neutralize the adverse effect of epiphytic algae on biomass accumulation of $V$. natans, probably because the growth of epiphytic algae was inhibited by a high nitrate-N concentration. In the no epiphtic algae group, the biomass of $V$. natans gradually increased as the nitrate- $\mathrm{N}$ concentration increased from $0.5 \mathrm{mg} / \mathrm{L}$ to $10 \mathrm{mg} / \mathrm{L}$, indicating that the nitrate- $\mathrm{N}$ concentrations in this experiment could slightly promote the biomass accumulation of $V$. natans.

It has been suggested that the host plants are simply inert platforms of epiphytic algae [49]. However, Wetzel [50] and Allen [51] suggested that host plants could exert considerable influence on periphyton. Under stress conditions, secondary metabolites largely accumulated in $V$. natans and were released from the surface of leaves, which promoted the growth of attached epiphytic algae and affected its community composition [52,53]. In turn, the overgrowth of epiphytic algae influenced the biomass and physiology of $V$. natans. In this study, the biomass of epiphytic algae was higher when the nitrate- $\mathrm{N}$ concentration was $2.5-5 \mathrm{mg} / \mathrm{L}$. When the nitrate- $\mathrm{N}$ concentration went up to $10 \mathrm{mg} / \mathrm{L}$, epiphytic algal biomass decreased, which may be due to the limited phosphorus content in the water column and an adverse effect produced by increasing nitrate- $\mathrm{N}$ concentration. Meanwhile, the dominant species of the epiphytic algal community changed a lot under different nitrate-N concentrations. This result may be due to the allelopathy of $V$. natans or the adaption to the change of nutrient conditions by the epiphytic algal community itself [54].

Chlorophyll is the most important pigment which is responsible for the absorption and transformation of light energy for photosynthesis in plants, so chlorophyll content is closely linked to photosynthetic intensity. The change of chlorophyll content could reflect the change of plant photosynthesis under stress conditions $[55,56]$. In the present study, the total chlorophyll content in leaves of $V$. natans showed an increase as nitrate-N increased from $0.5 \mathrm{mg} / \mathrm{L}$ to $5 \mathrm{mg} / \mathrm{L}$, but a reduction when nitrate-N increased from $5 \mathrm{mg} / \mathrm{L}$ to $10 \mathrm{mg} / \mathrm{L}$ in both the epiphytic algae group and no epiphytic algae group. The chl-a/chl-b ratio in leaves of $V$. natans in the epiphytic algae group decreased at $0.5-5 \mathrm{mg} / \mathrm{L}$ nitrate- $\mathrm{N}$ and increased at $10 \mathrm{mg} / \mathrm{L}$ nitrate- $\mathrm{N}$, while the ratio in the no epiphytic algae group decreased as nitrate- $\mathrm{N}$ rose from 0.5 to $10 \mathrm{mg} / \mathrm{L}$. It could be concluded that the increasing nitrate- $\mathrm{N}$ contents in the water column promoted the photosynthetic intensity of $V$. natans when the nitrate-N concentration was not over $5 \mathrm{mg} / \mathrm{L}$. When the nitrate- $\mathrm{N}$ concentration was $10 \mathrm{mg} / \mathrm{L}$, nitrate-N directly caused the decline of chlorophyll content in plants. The chl-a/chl-b ratio reflecting the light utilization efficiency of photosynthesis in leaves of plants suggested that epiphytic algae aggravated the adverse influence on light utilization efficiency of $V$. natans at $2.5-5 \mathrm{mg} / \mathrm{L}$ nitrate-N in the water column, when epiphytic algal biomass was reaching a high level. This result was consistent with the demonstration that an epiphytic algal boom resulted in the decline of chl-a density in the leaves of plants $[33,34]$.

Under stress or aging, antioxidant enzymes form a protective system in plants. When the stress is too strong, the system breaks down, lots of active oxygen accumulates in plants and causes membrane lipid peroxidation, and damage to plants is eventually observed [46]. MDA is one of the end products of membrane lipid peroxidation and can be used as an important index of physiological stresses [57]. The change of MDA content in plants indicates the degree of membrane damage of plant cells by stress [58]. In this study, the MDA content of $V$. natans in the epiphytic algae group showed slight increases as the nitrate- $\mathrm{N}$ concentration increased from 0.5 to $10 \mathrm{mg} / \mathrm{L}$. However, in the no epiphytic algae group, the MDA content showed an obvious increase. This result indicates that epiphytic algae specimens have obvious effects on the membrane lipid peroxidation of $V$. natans, as did an elevated nitrate-N concentration. Compared with the no epiphytic algae group, the MDA content 
in the epiphytic algae group showed little increase under the pressure of both epiphytic algae and increasing nitrate-N concentration, which can probably be explained by the fact that the increased antioxidative response alleviated or prevented lipid peroxidation [21,22].

Free proline will largely accumulate in plants under stress conditions, such as salinization and drought. It has a strong capacity of water binding, which makes it really important in osmotic adjustment in plants under osmotic stress conditions, and can be a physiological index of stress resistance. Some previous studies illustrated that free proline could serve as an indicator for unbalanced nitrogen nutrition $[59,60]$. In this study, in both epiphytic algae groups, the free proline content of $V$. natans increased when the nitrate-N concentration was $0.5-5 \mathrm{mg} / \mathrm{L}$, indicating that $V$. natans could synthesize proline as a compatible compound to sequester excessive nitrogen. When the nitrate-N concentration was 5-10 $\mathrm{mg} / \mathrm{L}$, the decrease of free proline content could probably be explained by the fact that the tissues of $V$. natans leaves were damaged resulting from a high concentration of nitrate-N in the water column. The results suggest that the capacity of this mechanism to sequester nitrogen is limited for $V$. natans, which only worked when the nitrate-N concentration was not over $5 \mathrm{mg} / \mathrm{L}$.

Soluble carbohydrates, as important metabolites in plant metabolism, play a crucial role in the plant defending system against infection and wounds, as well as in the detoxification of foreign substances [61]. The content of soluble carbohydrates in plants is liable to be effected by external stress [62]. In our study, the soluble carbohydrates content of $V$. natans in the epiphytic algae group increased when nitrate- $\mathrm{N}$ was $0.5-2.5 \mathrm{mg} / \mathrm{L}(p<0.05)$, and decreased when nitrate-N was $2.5-10 \mathrm{mg} / \mathrm{L}$; meanwhile, it was lower than that in the no epiphytic algae group with no significant differences $(p>0.05)$. Our findings suggest that nitrate- $\mathrm{N}$ content below $2.5 \mathrm{mg} / \mathrm{L}$ could promote the accumulation of soluble carbohydrates, but has an inverse effect when nitrate- $\mathrm{N}$ is $5-10 \mathrm{mg} / \mathrm{L}$. Epiphytic algae would cause a reduction of soluble carbohydrates in all nitrate- $\mathrm{N}$ concentrations compared with the no epiphytic algae group, but this phenomenon is indistinctive and more further studies are expected. The reduction of soluble carbohydrates may possibly be explained by the detoxification of nitrate- $\mathrm{N}$ in plant cells. Soluble carbohydrates can be used as energy sources to support the complex detoxification processes, such as the removal of nitrate- $\mathrm{N}$ from the plant cells and assimilation to free amino acids [63].

The changes of soluble proteins content in plants under stress conditions are responsible for adaption in metabolic pathways [64]. Protein synthesis and degradation respond differently to stress conditions according to the stress resistance of plants. Yan et al. [65] found that protein contents increased in Hydrilla verticillata at $0.5-4 \mathrm{mg} / \mathrm{L}$ ammonia-N, but decreased sharply at $4-16 \mathrm{mg} / \mathrm{L}$ ammonia-N. In the present study, soluble proteins content in $V$. natans in the epiphytic algae group showed a remarkable increase at $0.5-2.5 \mathrm{mg} / \mathrm{L}$ nitrate- $\mathrm{N}(p<0.05)$, but a prominent reduction at $2.5-10 \mathrm{mg} / \mathrm{L}$ nitrate-N $(p<0.05)$. A similar trend could be observed in the no epiphytic algae group but was less significant between treatments $(p>0.05)$. Under moderate stress imposed by epiphytic algae and nitrate- $\mathrm{N}$, soluble proteins in $V$. natans could probably accumulate as compatible compounds to release stress in plant cells. Given excessive stress, the reduction of soluble proteins content may be caused by protein degradation under stress [66], or by protein fragmentation due to the toxicity of reactive oxygen species [67].

A stress situation can impose a prominent effect on physiological changes in plants by inducing reactive oxygen species (ROS) in cells and tissues to cause damage [55]. SOD, POD, and CAT are important anti-oxidant enzymes in the protective defense system to eliminate or reduce ROS in plants. The capacity of the anti-oxidant defense system often increases under stress conditions [68]. Yu et al. [69] showed that, when N/P concentrations exceeded 400/25 $\mu \mathrm{mol} / \mathrm{L}$ in overlying water, SOD, POD, and CAT activities decreased. Su et al. [55] implied that the activity of SOD in Egeria densa apical shoots increased with elevated ammonia-N (1-60 mg/L) and prolonged exposure. However, in the present study, SOD, POD, and CAT activities of $V$. natans in the epiphytic algae group increased when the nitrate- $\mathrm{N}$ concentration was $0.5-5 \mathrm{mg} / \mathrm{L}$ and remained nearly constant or decreased when nitrate- $\mathrm{N}$ was $5-10 \mathrm{mg} / \mathrm{L}$, while a sustained increase occurred in the no epiphytic algae group. This result suggests that the stress resistance of $V$. natans was compromised by over-high stress exerted by 
epiphytic algae and over-high nitrate-N concentration. Compared to the no epiphytic algae group, SOD, POD, and CAT activities of $V$. natans in the epiphytic algae group were prominently higher $(p<0.05)$ when nitrate- $\mathrm{N}$ was $5 \mathrm{mg} / \mathrm{L}$, which may be the result of a synergetic effect of epiphytic algae and increased nitrate- $\mathrm{N}$ concentration.

\section{Conclusions}

1. Increasing nitrate- $\mathrm{N}$ concentration in the water column affected the growth of epiphytic algae on $V$. natans. Epiphytic algal biomass attached on leaves of $V$. natans reached the peak when the nitrate- $\mathrm{N}$ concentration was $2.5-5 \mathrm{mg} / \mathrm{L}$, then decreased when nitrate- $\mathrm{N}$ was higher.

2. High density of epiphytic algae could significantly inhibit the biomass accumulation of $V$. natans, while increasing the nitrate- $\mathrm{N}$ concentration $(2.5 \mathrm{mg} / \mathrm{L}-10 \mathrm{mg} / \mathrm{L})$ in the water column, which could counteract the adverse effect of epiphytic algae and promote the biomass accumulation of V. natans.

3. Both epiphytic algae and a high nitrate-N concentration (above $5 \mathrm{mg} / \mathrm{L}$ ) could severally or synergistically produce adverse effects on $V$. natans by influencing physiological indexes, which could hurt and inhibit the growth of $V$. natans.

This study provided direct evidence that the recession of submerged macrophytes is directly related to the overgrowth of epiphytic algae. Meanwhile, a high density of epiphytic algae and increasing nitrate- $\mathrm{N}$ concentration in the water column can synergistically exert severe stress on the physiology of submerged macrophytes which may lead to a recession.

Acknowledgments: This study was supported by Major Science and Technology Program for Water Pollution Control and Treatment of China 12th Five-Year Plan (No. 2012ZX07101007-005), Hubei Provincial Natural Science Foundation of China (No. 2014CFB282), the State Key Laboratory of Freshwater Ecology and Biotechnology (No. 2017FB05), and the Knowledge Innovation Program of the Chinese Academy of Sciences. We would like to thank Lilian Wen for a constructive review and detailed suggestions for improving this manuscript.

Author Contributions: Biyun Liu, Fenli Min, Feng He, and Zhenbin Wu conceived and designed the experiments; Fenli Min, Jincheng Zuo, Yi Zhang, and Qingwei Lin performed the experiments; Fenli Min, Jian Sun, and Lei Zeng analyzed the data; Fenli Min, Biyun Liu, and Feng He together wrote the paper.

Conflicts of Interest: The authors declare no conflict of interest.

\section{References}

1. Beklioğlu, M.; Bucak, T.; Coppens, J.; Bezirci, G.; Tavşanoğlu, Ü.N.; Çakıroğlu, A.İ.; Levi, E.E.; Erdoğan, Ş.; Filiz, N.; Özkan, K.; et al. Restoration of eutrophic lakes with fluctuating water levels: A 20-year monitoring study of two inter-connected lakes. Water 2017, 9, 127. [CrossRef]

2. Zhang, Y.; Liu, X.; Qin, B.; Shi, K.; Deng, J.; Zhou, Y. Aquatic vegetation in response to increased eutrophication and degraded light climate in Eastern Lake Taihu: Implications for lake ecological restoration. Sci. Rep. 2016, 6, 23867. [CrossRef] [PubMed]

3. Orth, R.J.; Carruthers, T.J.B.; Dennison, W.C.; Duarte, C.M.; Fourqurean, J.W.; Heck, K.L., Jr.; Hughes, A.R.; Kendrick, G.A.; Kenworthy, W.J.; Olyarnik, S.; et al. A global crisis for seagrass ecosystems. AIBS Bull. 2006, 56, 987-996. [CrossRef]

4. Van Donk, E.; van de Bund, W.J. Impact of submerged macrophytes including charophytes on phyto- and zooplankton communities: Allelopathy versus other mechanisms. Aquat. Bot. 2002, 72, 261-274. [CrossRef]

5. Rodrigo, M.A.; Rojo, C.; Alonso-Guillén, J.L.; Vera, P. Restoration of two small Mediterranean lagoons: The dynamics of submerged macrophytes and factors that affect the success of revegetation. Ecol. Eng. 2013, 54, 1-15. [CrossRef]

6. Gonzalez-Sagrario, M.A.; Jeppesen, E.; Goma, J.; Søndergaard, M.; Jensen, J.P.; Lauridsen, T.; Landkildehus, F. Does high nitrogen loading prevent clear-water conditions in shallow lakes at moderately high phosphorus concentrations? Freshw. Biol. 2005, 50, 27-41. [CrossRef]

7. Wang, H.; Wang, H.; Liang, X.; Wu, S. Total phosphorus thresholds for regime shifts are nearly equal in subtropical and temperate shallow lakes with moderate depths and areas. Freshw. Biol. 2014, 59, 1659-1671. [CrossRef] 
8. Schindler, D.W. Eutrophication and recovery in experimental lakes: Implications for lake management. Science 1974, 184, 897-899. [CrossRef] [PubMed]

9. Sand-Jensen, K.; Pedersen, N.L.; Thorsgaard, I.; Moeslund, B.; Borum, J.; Brodersen, K.P. 100 years of vegetation decline and recovery in Lake Fure, Denmark. J. Ecol. 2008, 96, 260-271. [CrossRef]

10. Moss, B.; Jeppesen, E.; Søndergaard, M.; Lauridsen, T.L.; Liu, Z.W. Nitrogen, macrophytes, shallow lakes and nutrient limitation: Resolution of a current controversy? Hydrobiologia 2013, 710, 3-21. [CrossRef]

11. Yu, Q.; Wang, H.; Li, Y.; Shao, J.; Liang, X.; Jeppesen, E.; Wang, H. Effects of high nitrogen concentrations on the growth of submersed macrophytes at moderate phosphorus concentrations. Water Res. 2015, 83, 385-395. [CrossRef] [PubMed]

12. Barker, T.; Hatton, K.; O'Connor, M.; Connor, L.; Moss, B. Effects of nitrate load on submerged plant biomass and species richness: Results of a mesocosm experiment. Fundam. Appl. Limnol. 2008, 173, 89-100. [CrossRef]

13. James, C.; Fisher, J.; Russell, V.; Collings, S.; Moss, B. Nitrate availability and hydrophyte species richness in shallow lakes. Freshw. Biol. 2005, 50, 1049-1063. [CrossRef]

14. Food and Agriculture Organization Corporate Statistical Database (FAOSTAT). Fertilizers Consumption 2002-2012; Food and Agricultural Organization of the United Nations: Rome, Italy, 2014.

15. Iversen, T.M.; Grant, K.; Nielsen, K. Nitrogen enrichment of European inland and marine waters with special attention to Danish policy measures. Environ. Pollut. 1998, 102, 771-780. [CrossRef]

16. International Lake Environment Committee (ILEC). World Lakes Database, Survey of the State of World Lakes; ILEC: Kusatsu, Japan, 2004.

17. Wetzel, R.G. Limnology, Lake and River Ecosystems; Academic Press: London, UK, 2001.

18. Best, M.D.; Mantai, K.E. Growth of Myriophyllum: Sediment or lake water as the source of nitrogen and phosphorus. Ecology 1978, 59, 1075-1080. [CrossRef]

19. Gu, J.; Xu, Z.; Jin, H.; Ning, X.; He, H.; Yu, J.; Jeppesen, E.; Li, K. Response of Vallisneria natans to increasing nitrogen loading depends on sediment nutrient characteristics. Water 2016, 8, 563. [CrossRef]

20. Burkholder, J.M.; Mason, K.M.; Glasgow, H.B. Water column nitrate enrichment promotes decline of eelgrass Zostera marina: Evidence from seasonal mesocosm experiments. Mar. Ecol. Prog. Ser. 1992, 81, 163-178. [CrossRef]

21. Wang, C.; Zhang, S.; Wang, P.; Hou, J.; Li, W.; Zhang, W.J. Metabolic adaptations to ammonia-induced oxidative stress in leaves of the submerged macrophyte Vallisneria natans (Lour.) Hara. Aquat. Toxicol. 2008, 87, 88-98. [CrossRef] [PubMed]

22. Zhang, L.; Wang, S.; Jiao, L.; Zhao, H.; Zhang, Y.; Li, Y. Physiological response of a submerged plant (Myriophyllum spicatum) to different $\mathrm{NH}_{4} \mathrm{Cl}$ concentrations in sediments. Ecol. Eng. 2013, 58, 91-98. [CrossRef]

23. Phillips, G.L.; Eminson, D.; Moss, B. A mechanism to account for macrophyte decline in progressively eutrophicated freshwaters. Aquat. Bot. 1978, 4, 103-126. [CrossRef]

24. Romo, S.; Villena, M.M.A. Epiphyton, phytoplankton and macrophyte ecology in a shallow lake under in situ experimental conditions. Fundam. Appl. Limnol. 2007, 170, 197-209. [CrossRef]

25. Xing, W.; Wu, H.; Hao, B.; Liu, G. Stoichiometric characteristics and responses of submerged macrophytes to eutrophication in lakes along the middle and lower reaches of the Yangtze River. Ecol. Eng. 2013, 54, 16-21. [CrossRef]

26. He, H.; Liu, X.; Liu, X.; Yu, J.; Li, K.; Guan, B.; Jeppesen, E.; Liu, Z. Effects of cyanobacterial blooms on submerged macrophytes alleviated by the native Chinese bivalve Hyriopsis cumingii: A mesocosm experiment study. Ecol. Eng. 2014, 71, 363-367. [CrossRef]

27. Van Geest, G.J.; Coops, H.; Roijackers, R.M.M.; Buijse, A.D.; Scheffer, M. Succession of aquatic vegetation driven by reduced water-level fluctuations in floodplain lakes. J. Appl. Ecol. 2005, 42, 251-260. [CrossRef]

28. Sayer, C.D.; Burgess, A.; Kari, K.; Davidson, T.A.; Peglar, S.; Yang, H.; Rose, N. Long-term dynamics of submerged macrophytes and algae in a small and shallow, eutrophic lake: Implications for the stability of macrophyte-dominance. Freshw. Biol. 2010, 55, 565-583. [CrossRef]

29. Jones, J.I.; Sayer, C. Does fish invertebrate periphyton cascade precipitate plant loss in shallow lakes? Ecology 2003, 84, 2155-2167. [CrossRef]

30. Bécares, E.; Gomá, J.; Fernández-Aláez, M.; Fernández-Aláez, C.; Romo, S.; Miracle, M.R.; Ståhl-Delbanco, A.; Hansson, L.A.; Gyllström, M.; Van de Bund, W.J.; et al. Effects of nutrients and fish on periphyton and plant biomass across a European latitudinal gradient. Aquat. Ecol. 2008, 42, 561-574. [CrossRef] 
31. Fong, C.; Lee, S.; Wu, R. The effects of epiphytic algae and their grazers on the intertidal seagrass Zostera japonica. Aquat. Bot. 2000, 67, 251-261. [CrossRef]

32. Sand-Jensen, K.; Søndergaard, M. Phytoplankton and epiphyte development and their shading effect on submerged macrophytes in lakes of different nutrient status. Int. Rev. Hydrobiol. 1981, 66, 529-552. [CrossRef]

33. Asaeda, T.; Sultana, M.; Manatunge, J.; Fujino, T. The effect of epiphytic algae on the growth and production of Potamogeton perfoliatus L. in two light conditions. Environ. Exp. Bot. 2004, 52, 225-238. [CrossRef]

34. Chen, C.; Yin, D.; Yu, B.; Zhu, H. Effect of epiphytic algae on photosynthetic function of Potamogeton crispus. J. Freshw. Ecol. 2007, 22, 411-420. [CrossRef]

35. Hilt, S.; Gross, E.M. Can allelopathically active submerged macrophytes stabilize clear-water states in shallow lakes? Basic Appl. Ecol. 2008, 9, 422-432. [CrossRef]

36. Dent, C.L.; Cumming, G.S.; Carpenter, S.R. Multiple states in river and lake ecosystems. Philos. Trans. R. Soc. Lond. B 2002, 357, 635-645. [CrossRef] [PubMed]

37. Scheffer, M.; Carpenter, S.; Foley, J.A.; Folke, C.; Walker, B. Catastrophic shifts in ecosystems. Nature 2001, 413, 591-596. [CrossRef] [PubMed]

38. Song, Y.; Kong, F.; Xue, Y.; Qin, B. Responses of chlorophyll and MDA of Vallisneria natans to nitrogen and phosphorus availability and epiphytic algae. J. Freshw. Ecol. 2015, 30, 85-97. [CrossRef]

39. Yi, K.; Dai, Z.; Liu, B.; Lin, Q.; Zeng, L.; Xu, D.; He, F.; Wu, Z. Effects of vertical location and artificial substrate on colonization of algal periphyton. Acta Ecol. Sin. 2016, 36, 4864-4872.

40. Arnon, D.I. Copper enzymes in isolated chloroplasts. Polyphenoloxidase in beta vulgaris. Plant Physiol. 1949, 24, 1-15. [CrossRef] [PubMed]

41. Zhang, Z.; Huang, X. Freshwater Plankton Research Methods; Science Press: Beijing, China, 1991.

42. Heath, R.L.; Packer, L. Photoperoxidation in isolated chloroplasts: I. Kinetics and stoichiometry of fatty acid peroxidation. Arch. Biochem. Biophys. 1968, 125, 189-198. [CrossRef]

43. Bates, L.S.; Waldren, R.P.; Teare, I.D. Rapid determination of free proline for water-stress studies. Plant Soil 1973, 39, 205-207. [CrossRef]

44. Yemm, E.W.; Willis, A.J. The estimation of carbohydrates in plant extracts by anthrone. Biochemistry 1954, 57, 508-514. [CrossRef]

45. Bradford, M.M. Arapid and sensitive method for the quantitation of microgram quantities of protein utilizing the principle of protein-dye binding. Anal. Biochem. 1976, 72, 248-254. [CrossRef]

46. Li, H. The Experiment Principle and Technology of Plant Physiology; Higher Education Press: Beijing, China, 2000; pp. 267-268.

47. Reigosa, M.J.; Sánchez-Moreiras, A.; González, L. Ecophysiological approach in allelopathy. Crit. Rev. Plant Sci. 1999, 18, 577-608. [CrossRef]

48. Song, Y.; Wang, J.; Gao, Y. Effects of epiphytic algae on biomass and physiology of Myriophyllum spicatum L. with the increase of nitrogen and phosphorus availability in the water body. Environ. Sci. Pollut. Res. 2017, 24, 9548-9555. [CrossRef] [PubMed]

49. Shelford, V.E. Conditions of Existence; Wiley: New York, NY, USA, 1918; pp. 21-60.

50. Wetzel, R.G. Attached algal-substrata interactions: Fact or myth, and when and how? In Periphyton of Freshwater Ecosystems; Junk: The Hague, The Netherlands, 1983; pp. 207-215.

51. Allen, H.L. Primary productivity, chemo-organo-trophy, and nutritional interactions of epiphytic algae and bacteria on macrophytes in the littoral of a lake. Ecol. Monogr. 1971, 41, 97-127. [CrossRef]

52. Thomas, J.D. Mutualistic interactions in freshwater modular systems with molluscan components. Adv. Ecol. Res. 1990, 20, 125-178.

53. Jones, I.J.; Moss, B.; Eaton, J.W.; Young, J.O. Do submerged aquatic plants influence periphyton community composition for the benefit of invertebrate mutualists? Freshw. Biol. 2000, 43, 591-604. [CrossRef]

54. Toporowska, M.; Pawlik-Skowrońska, B.; Wojtal, A.Z. Epiphytic algae on Stratiotes aloides L., Potamogeton lucens L., Ceratophyllum demersum L. and Chara spp. in a macrophyte-dominated lake. Oceanol. Hydrobiol. Stud. 2008, 2, 51-63. [CrossRef]

55. Su, S.; Zhou, Y.; Qin, J.; Wang, W.; Yao, W.; Song, L. Physiological responses of Egeria densa to high ammonium concentration and nitrogen deficiency. Chemosphere 2012, 86, 538-545.

56. Wu, W. Plant Physiology, 2nd ed.; Science Press: Beijing, China, 2012.

57. Chen, Y.; He, Y.; Luo, Y.; Yu, Y.; Lin, Q.; Wong, M. Physiological mechanism of plant roots exposed to cadmium. Chemosphere 2003, 50, 789-793. [CrossRef] 
58. Huang, W.; Jia, Z.; Han, Q. Effects of herbivore stress by Aphis medicaginis Koch on the malondialdehyde contents and the activities of protective enzymes in different alfalfa varieties. Acta Ecol. Sin. 2007, 27, 2177-2183.

59. Atanasova, E. Effect of nitrogen sources on the nitrogenous forms and accumulation of amino acid in Head Cabbage. Plant Soil Environ. 2008, 54, 66-71.

60. Neuberg, M.; Pavlíková, D.; Pavlík, M.; Balík, J. The effect of different nitrogen nutrition on proline and asparagine content in plant. Plant Soil Environ. 2010, 56, 305-311.

61. Harborne, J.B.; Turner, B.L. Plant Chemosysternatics; Academic Press: Cambridge, UK, 1984; pp. $216-232$.

62. Costa, G.; Spitz, E. Influence of cadmiumon soluble carbohydrates, free amino acids, protein content of In Vitro cultured Lupinus albus. Plant Sci. 1997, 128, 131-140. [CrossRef]

63. Touchette, B.W.; Burkholder, J.M. Review of nitrogen and phosphorus metabolism in seagrasses. J. Exp. Mar. Biol. Ecol. 2000, 250, 133-167. [CrossRef]

64. Amini, F.; Ehsanpour, A.A. Soluble proteins, proline, carbohydrates and $\mathrm{Na}^{+} / \mathrm{K}^{+}$changes in two tomato (Lycopersicon esculentum Mill.) Cultivars under in vitro salt stress. Am. J. Biochem. Biotechnol. 2005, 1, $204-208$. [CrossRef]

65. Yan, C.; Zeng, A.; Jin, X.; Zhao, J.; Xu, Q.; Wang, X. Physiological effects of ammonia-nitrogen concentrations on Hydrilla verticillata. Acta Ecol. Sin. 2007, 27, 1050-1055.

66. Palma, J.M.; Sandalio, L.M.; Corpas, F.J.; Romero-Puertas, M.C.; McCarthy, I.; Luis, A. Plant proteases protein degradation and oxidative stress: Role of peroxisomes. Plant Physiol. Biochem. 2002, 40, 521-530. [CrossRef]

67. John, R.; Ahmad, P.; Sharma, S. Effect of cadmium and lead on growth, biochemical parameters and uptake in Lemna polyrrhiza L. Plant Soil Environ. 2008, 54, 262-270.

68. Misra, N.; Gupta, A.K. Effect of salinity and different nitrogen sources on the activity of antioxidant enzymes and indole alkaloid content in Catharanthus roseus seedlings. J. Plant Physiol. 2006, 163, 11-18. [CrossRef] [PubMed]

69. Yu, J.; Yang, Y. Physiological and biochemical response of seaweed Gracilaria lemaneiformis to concentration changes of N and P. J. Exp. Mar. Biol. Ecol. 2008, 367, 142-148. [CrossRef]

(C) 2017 by the authors. Licensee MDPI, Basel, Switzerland. This article is an open access article distributed under the terms and conditions of the Creative Commons Attribution (CC BY) license (http:/ / creativecommons.org/licenses/by/4.0/). 